\title{
Work Discipline and Principal Leadership in Influencing Teachers' Performance
}

\author{
${ }^{1}$ SMP Negeri 2 Sumber Marga Telang \\ ${ }^{2}$ Universitas PGRI Palembang \\ *Corresponding author. Email: umiyatun936@gmail.com
}

Umi Nur Fudiyah ${ }^{1 *}$, Edi Harapan², Tahrun ${ }^{2}$

\begin{abstract}
Teacher performance in a school is inseparable from the role of work discipline and leadership of the principal as school leader and manager. The aim of this research was to see what impact of work discipline and principal leadership on teacher performance at SMP Negeri Talang Kelapa. This study used a quantitative method with a survey approach. The study's subjects were the principals and teachers. Data collection methods were using questionnaires and documentation. The instrument is done by using validity test and reliability test. Data analysis using descriptive and inferential data analysis techniques. The results showed: 1) The discipline of teacher work has a huge impact on the success of students at the Talang Kelapa District Middle School. 2) The principal's leadership has an effect on the success of the teachers at the Talang Kelapa District Middle School. 3) The combination of teacher job discipline and principal leadership has a direct impact on teacher success at the Talang Kelapa District Middle School.
\end{abstract}

Keywords: Work Discipline, Principal Leadership, Teacher Performance

\section{INTRODUCTION}

Education is a basic human need. Education is constantly evolving, expanding, and improving in response to changes in all aspects of life. The different elements involved in the field of education, including the implementers of education in the field (teacher expertise and quality of teaching staff), quality of education, instructional materials, educational facilities and resources, and quality of education administration, including shifts in learning practices and techniques that are more creative. These reforms and developments are targeted at improving the standard of Indonesian education, with a leader playing a role in one of them.

In education, teachers have an important role, even adequate other educational resources are often insignificant if they are not accompanied by adequate teacher quality, in other words, teachers are the spearhead in efforts to improve service quality and educational outcomes [1]. Thus, Teacher competence is one indicator of educational achievement.

Teacher performance has a direct effect on the quality of education of each student. The better the teacher's performance, the better the quality of education produced. That is, if the teacher has a good performance, the results of the teaching and learning process will also be good. For that performance plays an important role in achieving optimal teaching goals. Given the important role of this performance, schools need to improve teacher performance so that teaching objectives can be maximally achieved.

This research was conducted because some of the problems that the researchers found in the Talang Kelapa District Junior High School at this time turned out that there were still many things that should not be done by the teacher which had an impact on student discipline and achievement. On the preliminary observation, there still found that many teachers arrive $30 \%$ late, some teachers are still late for morning briefing and group prayers, and in the first lesson begins, the second is on making learning tools that are still copy paste. The other case was that there are still teachers who do not implement remedial enrichment of nearly $35 \%$, this was discovered when the school principal and supervisors supervised this.

It is predicted that low teacher performance is due to a lot of it coming from within the individual teacher and from outside. In addition, low teacher performance is influenced by, among others, competence, work 
discipline, job satisfaction, the organization where teachers teach, the leadership of the principal, as well as the existence of government policies on education. This is in line with Siagian's opinion [2] that work climate, workplace atmosphere, leadership and work morale, work ethic, pay, employee satisfaction, and other aspects all have an impact on success.

The principal's leadership has a direct effect on teacher performance and the greater the principal's leadership, the better the teachers' performance in carrying out their responsibilities as educators. This is also emphasized by Lestari [3] state states that principal leadership has a vital position to play in increasing teacher morale in carry out its duties so as to build a friendly and harmonious working environment. As a result, the teacher would be more passionate in encouraging students academically and socially. In addition, according to Ngiode [4], the principal's leadership inspires teachers to strive harder to achieve more results for their students.

This means that the The principal's leadership is critical in ensuring that teachers carry out their responsibilities adequately and that curriculum priorities are met to the greatest extent possible. This is evident from the results of research by Ngiode [4] from the results of his research, which shows that there is a positive and significant influence of principal leadership on teacher performance. In addition, the results of research conducted by Sulistia [5] show that the leadership of the principal has a significant effect. on teacher performance. In other words, the leadership of the principal may justify the level of teacher success.

In addition to the leadership factor of the principal, teacher performance is also influenced by work discipline. This is in line with research conducted by Sonang [6] in his research explaining that work discipline factors also play an important role in increasing the success of teaching teachers. Good work discipline is needed in achieving the expected goals. In general, work discipline can be defined as an attitude or behavior that is in accordance with the regulations of an organization, whether in writing or not.

Talking about work discipline has an influence on teacher performance in carrying out teachers, because discipline is very important because work discipline can be a driving force for the willingness and desire to work according to the established standards or limits so that it is clear that work discipline should be owned by a teacher in order to support the success of the learning process.

According to Sutrisno [7], good work discipline will improve employee performance, in this case the teacher, so as to accelerate the achievement of organizational goals, while low discipline will reduce employee performance so that It becomes a roadblock that delays the accomplishment of operational objectives. This is in line with research conducted by Aritonang [8], who shows that there is a significant positive relationship between teacher work discipline and performance in all BPK PENABUR Jakarta Christian Middle Schools. A disciplined teacher is defined as an instructor who both arrives and departs on schedule, completes all work correctly, and adheres to all organizational rules and social norms A person's sense of duty for the duties entrusted to him is reflected in good discipline. This fosters enthusiasm and confidence, as well as the achievement of corporate, employee, and group objectives.

\section{METHODS}

This research will be conducted at SMP Negeri Talang Kelapa District which is located in Palembang City, South Sumatra. This research will be conducted from September to November 2020. This research belongs to the quantitative research group. This study is focused on the effect of work discipline and principal leadership on teacher performance. It consists of several components that need to be improved, including teacher discipline, principal leadership style, principal strategy and teacher performance at SMP Negeri Talang Kelapa District. The data collection procedure uses a questionnaire and documentation method. The instrument testing technique uses validity and reliability tests. Meanwhile, the data requirements test used the data normality test, data homogeneity test, linearity test, and data multicollinearity test.

\section{RESULTS AND DISCUSSION}

The results of the simultaneous test of work discipline and principal leadership variables on teacher performance are known to be much smaller than 0.05 and Fcount is greater than Ftable, so H03 is rejected and $\mathrm{Ha} 3$ is accepted or in other words, there is an effect of work discipline and principal leadership together -same towards teacher performance so it can be said that the variables of work discipline and principal leadership and together have a significant effect on teacher performance. This further demonstrates that if the school principal's job ethic and leadership improves, teacher morale improves as well, and vice versa if the work discipline and leadership of the school principal decreases, it will be followed by a significant decrease in the performance of teachers at SMP Negeri in Talang Kelapa district.

The coefficient of determination test results also found that $49.9 \%$ of teacher performance variables can be explained by variables of teacher work discipline and principal leadership. While the remaining $50.1 \%$ is explained by reasons other than research variables such 
as competence, working conditions, compensation, and others. This can be seen in detail in table 1 below:

Table 1. Determination Coefficient Test Results

\section{Model Summary}

\begin{tabular}{ll|r|r|r} 
Model & R & R Square & \multicolumn{1}{c}{$\begin{array}{c}\text { Adjusted R } \\
\text { Square }\end{array}$} & $\begin{array}{l}\text { Std. Error of } \\
\text { the Estimate }\end{array}$ \\
\hline 1 & $.740^{\mathrm{a}}$ & .548 & .541 & .44649 \\
\hline
\end{tabular}

Table 1 shows that the value of R Square is 0.548 . This shows that $54.8 \%$ of the teacher performance variables can be explained by the variable of principal leadership and teacher work discipline. While the rest $(100 \%-54.8 \%=45.2 \%)$ is explained by reasons other than the research variables such as competence, working conditions and others.

The findings of this report corroborate those of a study performed by Tajuddin [9], who showed that job discipline and principal leadership have a positive impact on teacher succes, this meant getting better work discipline than teachers and teachers' perceptions of principal leadership, teacher achievement will also be better. He also advises teachers to improve work discipline and also be able to realize good teacher achievement. School heads must show good leadership by using a family approach so that they can realize the desired teacher achievement.

The findings of this report corroborate those of a previous study by Purwoko [10] who found that school leadership and job discipline had an effect on teacher achievement, that means getting better work discipline from teachers, will improve teacher achievement. The investigation by Syakir [11] also proved that the independent variables, including the principal's leadership, had a strong and meaningful joint impact and work discipline on the dependent variable, namely teacher performance. These results are also in line with the results of the study Nasrun [12] who states that Principal leadership and teacher work discipline and performance have a positive and significant relationship.

Principal leadership and teacher work discipline are very important factors in an effort to improve teacher achievement. Teachers of State Junior High Schools in Talang Kelapa District in particular should provide optimum performance by carrying out their duties and functions in educating students by carrying out classroom learning properly. By considering the results of descriptive statistics, it is found that the leadership of the principal and the work discipline of the teachers of SMP Negeri in Talang Kelapa district are classified as high, so that it will have an influence on high performance as well. Teachers who are of low achievement, and who are often called upon and receive guidance from the principal, must show a significant change in teacher attitudes. With direction, guidance from the principal as a leader and efforts to enforce discipline that has been done must increase teacher motivation in teaching, which in turn can improve the performance of these teachers.

In an effort to improve teacher performance, school As their subordinates, principals must pay attention to influences that influence teacher success. Many influences, both internal to the teacher and external to the school climate and government policy, will influence teacher success. The leader still wishes that the teacher he supervises will be able to reach higher levels of accomplishment.

As stated by Mulyasa [13] that several factors affect achievement or productivity, namely technology factors, values, work climate, health status and minimum salary levels, and leadership in this case the school principal. In line with this opinion, Sedarmayanti [14] argues that there are several factors that affect performance including: (1) mental attitude (work motivation, work discipline, work ethics, and work culture); (2) education; (3) proficiency; (4) leadership supervision; (5) Earnings potential; (6) Wage and Health; (7) Social Security and Welfare; (8) Working Environment; 9) Sufficient Services and Infrastructure; 10) Technology and (11) opportunities for achievement.

The role model of the principal of SMP Negeri in Talang Kelapa District as a leader also plays an important role in determining teacher performance, because the principal is made a role model by the teacher as his subordinate. The head of the school must set a good example, be well disciplined, honest and fair, and appropriate with words and deeds. The principal must realize that his behavior will be imitated by the teachers. Another case that also affects the realization of discipline so that teacher performance is improved is a sense of justice, because it will also encourage the realization of teacher discipline, so inherent supervision (waskat) is a real action and the most influential in realizing teacher discipline, because with this supervision means the principal must active and directly supervise the behavior, morals, attitudes, morale and work performance of teachers.

One other factor that helps to achieve work discipline is a harmonious human relationship and is closed with legal or statutory sanctions. Because with legal sanctions it will maintain discipline and teachers will be increasingly afraid to break the rules. The level of sanctions to be imposed also affects the discipline of good / bad teachers. Punishment should be determined based on a logical, reasonable and clear objective to all teachers. Punishment should not be too severe or light so that it continues to educate teachers to change their behavior. 
The principal as the holder of the highest rules in the school must also be able to improve the discipline of the teacher he leads, including through disciplinary activities either preventive or preventive before a violation occurs or corrective action is given for violations. Disciplinary activity is divided into two, namely: discipline of prevention and discipline of improvement. Preventive discipline is an activity carried out to allow teachers to adhere to different guidelines and laws in order to avoid violations The key goal is to inspire teachers to be more self-disciplined. In this way teachers can maintain their self-discipline not only because they are forced to but they are aware; Although corrective discipline is an activity that is taken to deal with violations of the rules and try to avoid further violations. Corrective activity often takes the form of punishment and is referred to as act of discipline. For example, disciplinary measures may take the form of a warning or suspension. With the discipline of teacher performance, it can be improved again [15].

From the explanation above, it is suggested that the principal as a leader is expected to maintain consistency in terms of motivating and increasing teacher work discipline in order for them to enhance their success in carrying out their roles and obligations in order to achieve the national education goals.

Table 2. Partial Test Result (t test)

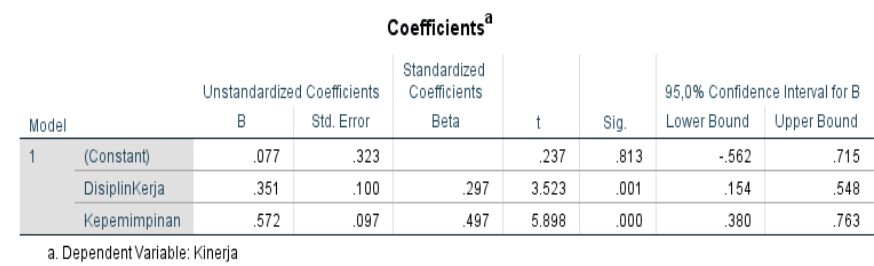

First Hypothesis: Ha1: $\beta 1 \neq 0$ : There is an effect of teacher work discipline on teacher performance

H01: $\beta 1=0$ : There is no effect of teacher work discipline on teacher performance.

The results of the t-test for the variable teacher work discipline (X1) on teacher performance (Y) show a sig value of 0.001 , which means that the significance value is smaller than the probability value of $0.05(0.001$ $<0.05)$ and the tcount shows a value of 3.523 meaning that $\mathrm{t}$ is greater than $\mathrm{t}$ table. $(3,523>2,01954)$. The conclusion is that $\mathrm{H} 01$ is rejected and Ha1 is accepted, meaning that there is an effect of teacher work discipline on teacher performance and it can be said that individual teacher work discipline variables have a significant effect on teacher performance. The coefficient value of the teacher work discipline variable is positive, indicating that increasing teacher work discipline is followed by an increase in teacher performance and vice versa if the teacher's work discipline decreases, followed by a significant decrease in teacher performance.
Second hypothesis:

Ha2: $\beta 2 \neq 0$ : There is an effect of the principal's leadership on teacher performance

H02: $\beta 2=0$ : There is no influence of the principal's leadership on teacher performance

The results of the t-test for the principal's leadership variable $(\mathrm{X} 2)$ on teacher performance $(\mathrm{Y})$ show a sig value of 0,000 , the significance value is less than the likelihood value, implying that the significance value is lower of $0.05(0,000<0.05)$ and tcount shows a value of 5.898 , meaning that the tcount is greater. from ttable $(5,898>2,01954)$. The conclusion is that $\mathrm{H} 02$ is rejected and $\mathrm{Ha} 2$ is accepted, or there is an influence of the principal's leadership on teacher performance so that it can be said that the individual principal leadership variable has a significant effect on teacher performance. The coefficient value of the principal's leadership variable is positive, indicating that the increase in teacher work discipline is followed by an increase in teacher performance and vice versa if the work discipline decreases, followed by a significant decrease in teacher performance.

Table 3. Simultaneous Test (Test F)

\begin{tabular}{|c|c|c|c|c|c|c|}
\hline \multicolumn{7}{|c|}{ ANOVA $^{\mathrm{a}}$} \\
\hline \multicolumn{2}{|c|}{ Model } & $\begin{array}{l}\text { Sum of } \\
\text { Squares }\end{array}$ & df & Mean Square & $F$ & Sig. \\
\hline \multirow[t]{3}{*}{1} & Regression & 32.081 & 2 & 16.041 & 80.462 & $.000^{b}$ \\
\hline & Residual & 26.514 & 133 & .199 & & \\
\hline & Total & 58.596 & 135 & & & \\
\hline
\end{tabular}

From Table 3, the simultaneous test results of the variables of teacher work discipline and principal leadership together on teacher performance are known to be Fcount is 80,462 with a significance level of 0,000 . Ftable 4.08 is obtained by looking at the $\mathrm{F}$ table with degrees $\mathrm{df}=\mathrm{k}-1(\mathrm{df}=2-1)$ and $\mathrm{df}=\mathrm{n}-\mathrm{k}(\mathrm{df}=43-2)$ at the 0.05 significance level. Because the probability (0.000) is much smaller than 0.05 and Fcount is greater than Ftable (19.912> 4.08), then H03 is rejected and $\mathrm{Ha} 3$ is accepted or in other words, there is an influence of the principal's leadership and teacher work discipline together. on teacher performance.

\section{CONCLUSION}

Referring to the results of the discussion, it can be concluded that several things related to this research include: Firstly, there is a significant influence between teacher work discipline on the performance of teachers at the Talang Kelapa District Middle School. Secondly, the leadership of the principal has an effect on teacher success of the Talang Kelapa District Middle School 
teachers. Thirdly, the combination of teacher job discipline and principal leadership has a direct impact on teacher success at the Talang Kelapa District Middle School.

\section{REFERENCES}

[1] Murwati, H. (2013). Pengaruh Sertifikasi Profesi Guru terhadap Motivasi Kerja dan Kinerja Guru di SMK Negeri Se- Surakarta. Jurnal Pendidikan Bisnisdan Ekonomi (BISE). Vol.1 No. 1.

[2] Siagian. (2013). Manajemen Sumber Daya Manusia. Jakarta: Bumi Aksara.

[3] Lestari, S. (2016). Pengaruh Kepemimpinan Kepala Sekolah dan Kinerja Guru terhadap Prestasi Siswa. Satya Widya, Vol. 32, No.2. Desember 2016: $127-132$

[4] Ngiode, S. (2016). Pengaruh Kepemimpinan Kepala Sekolah, Motivasi Kerja dan Disiplin Kerja terhadap Kinerja Guru MTs.N Batudaa Kabupaten Gorontalo. Tadbir:Jurnal Manajemen Pendidikan Islam, 4(2)

[5] Sulistiya, M. (2013). Pengaruh Kepemimpinan Kepala Sekolah Terhadap Kinerja Guru. Jurnal Ilmiah Pendidikan Ekonomi IKIP Veteran Semarang.Vol. 1 No. 2.

[6] Sonang, P. P. (2009). Pengaruh Motivasi Kerja dan Disiplin Kerja terhadap Kinerja Guru SMP Negeri 54 Palembang. Junal Manajemen Universitas Tridiananti Palembang.

[7] Sutrisno, E. (2011). Manajemen Sumber Daya Manusia. Jakarta: Kencana.

[8] Aritonang, K. T. (2015). "Kompensasi Kerja, dan Kinerja Guru SMP Kristen BPK Penabur Jakarta. Jurnal Pendidikan Penabur, 4(4).

[9] Tajuddin, M. (2015). Modification of Delon and McLean model in the success of information system for good university governance. Turkish Online Journal of Educational Technology.

[10] Purwoko, S. (2018). Pengaruh kepemimpinan kepala sekolah, komitmen guru, disiplin kerja guru, dan budaya sekolah terhadap kinerja guru SMK. Jurnal Akuntabilitas Manajemen Pendidikan. https://doi.org/10.21831/amp.v6i2.8467.

[11] Syakir, M. J., \& Pardjono. (2015). Pengaruh Kepemimpinan Kepala Sekolah, Motivasi Kerja, dan Budaya Organisasi terhadap Kompetensi Guru SMA. Jurnal Akuntabilitas Manajemen Pendidikan. Volume 3, No 2, September 2015 (226240). ISSN: 2337-7895 e-ISSN: 2461-0550.
[12] Nasrun, N. (2016). Pengaruh Kepemimpinan Kepala Sekolah Terhadap Motivasi Kerja dan Kinerja Guru. Ilmu Pendidikan: Jurnal Kajian Teori Dan Praktik Kependidikan. https://doi.org/10.17977/um027v1i22016p063.

[13] Mulyasa. (2013). uji kompetensi dan penilaian kinerja guru. In uji kompetensi dan penilaian kinerja guru.

[14] Sedarmayanti. (2010). Manajemen Sumber Daya Manusia. In E-Jurnal Manajemen Universitas Udayana.

[15] A. Pnueli, In transition from global to modular temporal reasoning about programs, in: K.R. Apt (Ed.), Logics and Models of Concurrent Systems, Springer, Berlin, Heidelberg, 1984, pp. 123-144. DOI: https://doi.org/10.1007/978-3-642-82453-1_5 